\title{
Diel differences in the exploitation of shallow inshore habitats by three small bottom-dwelling fishes with implications for their monitoring in a large lowland river
}

\author{
Michał Nowak, Artur Klaczak, Paweł Szczerbik, Włodzimierz Popek
}

Received - 20 August 2018/Accepted - 24 September 2018. Published online: 30 September 2018; @Inland Fisheries Institute in Olsztyn, Poland Citation: Nowak M., Klaczak A., Szczerbik P., Popek W. 2018 - Diel differences in the exploitation of shallow inshore habitats by three small bottom-dwelling fishes with implications for their monitoring in a large lowland river - Fish. Aquat. Life 26: 159-164.

\begin{abstract}
Sampling small-bodied fish species in large lowland rivers poses numerous difficulties often resulting in the underestimation of their true distribution and abundance. Some of these drawbacks might be overcome by using additional sampling gears and adapting sampling strategies to the biological specifications of the target species. The results of a two-year, repeated survey on a single location on the Vistula River (southern Poland) revealed that nighttime beach seining proved to be very effective in collecting specimens of three imperiled species: Romanogobio belingi, Romanogobio kesslerii, and Sabanejewia baltica. It was found that these species were 4.3-8.8 times more abundant in nighttime than in daytime collections. The abundance of all three species peaked at dusk and gradually decreased in subsequent hours. In conclusion, nighttime beach seining is recommended as a supplementary sampling technique for small bottom-dwelling fish species in large lowland rivers.
\end{abstract}

Keywords: day vs. night sampling, Natura 2000, rare species, temporal variation, Vistula River

\footnotetext{
M. Nowak ["

Department of Ichthyobiology and Fisheries

University of Agriculture in Kraków

Spiczakowa 6, 30-198 Kraków, Poland

Present address:

M. Nowak

"Mazanów" Fish Farm

Mazanów 8A, 24-340 Józefów nad Wisłą, Poland

e-mail: mikhael.nowak@gmail.com
}

\section{Introduction}

Large rivers are especially difficult for monitoring small-bodied, bottom-dwelling fish species. Wide riverbeds, deep waters, swift currents, and the complexity of river systems often make sampling extremely inefficient (Casselman et al. 1990, De Leeuw et al. 2007, Lapointe et al. 2008, Freedman et al. 2009, Herzog et al. 2009, Szalóky et al. 2014, Zajicek and Wolter 2018). In some rivers additional difficulty arises from very high water conductivity (e.g., in the Vistula River the conductivity regularly reaches $1500-2000 \mu \mathrm{S} \mathrm{cm}^{-1}$ and often exceeds even 3000 $\mu \mathrm{S} \mathrm{cm}^{-1}$ ) making electrofishing nearly impossible and inefficient. For these reasons various approaches have been developed to deal with these difficulties and to maximize sampling efficiency and precision. To obtain these goals, often specific sampling gears are used or data from multiple gears are used jointly (Casselmann et al. 1990, Lapointe et al. 2008, Freedman et al. 2009, Herzog et al. 2009, Szalóky et al. 2014, Zajicek and Wolter 2018) or sampling design is modified to meet specific aspects of the ecology of a certain species of interest (Johnson and Covich 2000, Kocovsky et al. 2010, Nunn et al. 2014). 
One of the biological phenomena that might be incorporated into monitoring design are diel differences in exploitation of certain habitats by particular fish species. This diel changeover of fish assemblages in shallow habitats has been described for rivers of various sizes in different climate zones (Copp 2010 and literature cited therein).

In this paper we describe diel differences in the abundance of three small-bodied, bottom-dwelling fish species listed in the Annex II of the Habitat Directive; thus, they are subjects of regional- and EU-level monitoring. The whitefin gudgeon, Romanogobio belingi (Slastenenko, 1934), and the golden loach, Sabanejewia baltica (Witkowski, 1994), are listed as vulnerable (VU), whereas Kessler's gudgeon, Romanogobio kesslerii (Dybowski, 1862), as near threatened (NT) on the Polish regional red list (Witkowski et al. 2009). All three are considered rare species with small local populations. In recent years numerous new locations of $R$. belingi and, to a lesser extent, of $R$. kesslerii were found throughout Poland, and it was even hypothesized that they might be undergoing expansion (Nowak et al. 2013, 2014). The reverse trend has been observed recently for $S$. baltica, which has declined in or completely disappeared from a number of locations (Kotusz 2017). However, the only sampling technique for all these species approved by national institutions is electrofishing (Makomaska-Juchiewicz and Baran 2012). It is suspected that this method is strongly biased against small-bodied fishes in large rivers, resulting in numerous false-negative records and the severe underestimation of their population parameters. For this reason in the present study we propose an alternative, or rather supplementary, technique for sampling $R$. belingi, $R$. kesslerii, and S. baltica in large lowland rivers.

\section{Material and methods}

Sampling was performed in a shallow sandy habitat formed between old dykes on the left bank of the Vistula River close to the village of Łęka near Nowy
Korczyn (lat. $50.28272^{\circ} \mathrm{N}$, long. $20.84982^{\circ} \mathrm{E}$ ). The river bed in this location is $160-230 \mathrm{~m}$ wide and the average discharge is approximately $220 \mathrm{~m}^{3} \mathrm{~s}^{-1}$ (during periods with discharge greater than $300 \mathrm{~m}^{3} \mathrm{~s}^{-1}$ sampling is impossible because of water depth greater than $1.3 \mathrm{~m}$ over the sandbar). Fish were caught using a 15-m-long seine net (two $5 \times 1.5 \mathrm{~m}$ wings and a central bag of $5 \times 3 \mathrm{~m}$ made of knotless nylon netting, bar mesh size $=8 \mathrm{~mm}$ ), hauled downstream at approximately $50 \mathrm{~m}$ transects. Samples were taken every $3 \mathrm{~h}$ over a $24 \mathrm{~h}$ period from August 2014 to March 2016 (a total of seven sampling sessions: August 21-22, 2014; November 5-6, 2014; March 9-10, 2015; May 7-8, 2015; July 7-8, 2015; December 17-18, 2015; March 16-17, 2016). After capture, the fish were measured (standard length, SL $\pm 1 \mathrm{~mm}$ ) and released back into the water. At each sampling event, illumination at the water surface was measured ( $\pm 1 \mathrm{~lx}$, Milwaukee MW700 lux meter), and dusk was considered to be the time when illumination dropped below $0.001 \mathrm{klx}$.

The data are presented as CPUE (number of specimens caught in a single haul). To obtain 95\% confidence intervals for the mean CPUE, we applied the bootstrapping technique (10,000 iterations; Haddon 2011). Diel differences in the CPUE of every species were investigated with generalized linear mixed-effects models (GLMM) with Poisson distribution for error and the log-link function. As 24-h variation was of primary interest, we set season (spring, summer, fall, and winter) as the random effect. The calculations were performed in the R environment (R Core Team 2018) with the rcompanion (Mangiafico 2018) and lme4 packages (Bates et al. 2015).

\section{Results}

During the study, a total of 1,812 specimens belonging to 24 fish species were collected. The most abundant species were dace, Leuciscus leuciscus (L.), and bleak, Alburnus alburnus (L.). They constituted up to $10.8 \%$ and $8.9 \%$ of the total, respectively. The next 


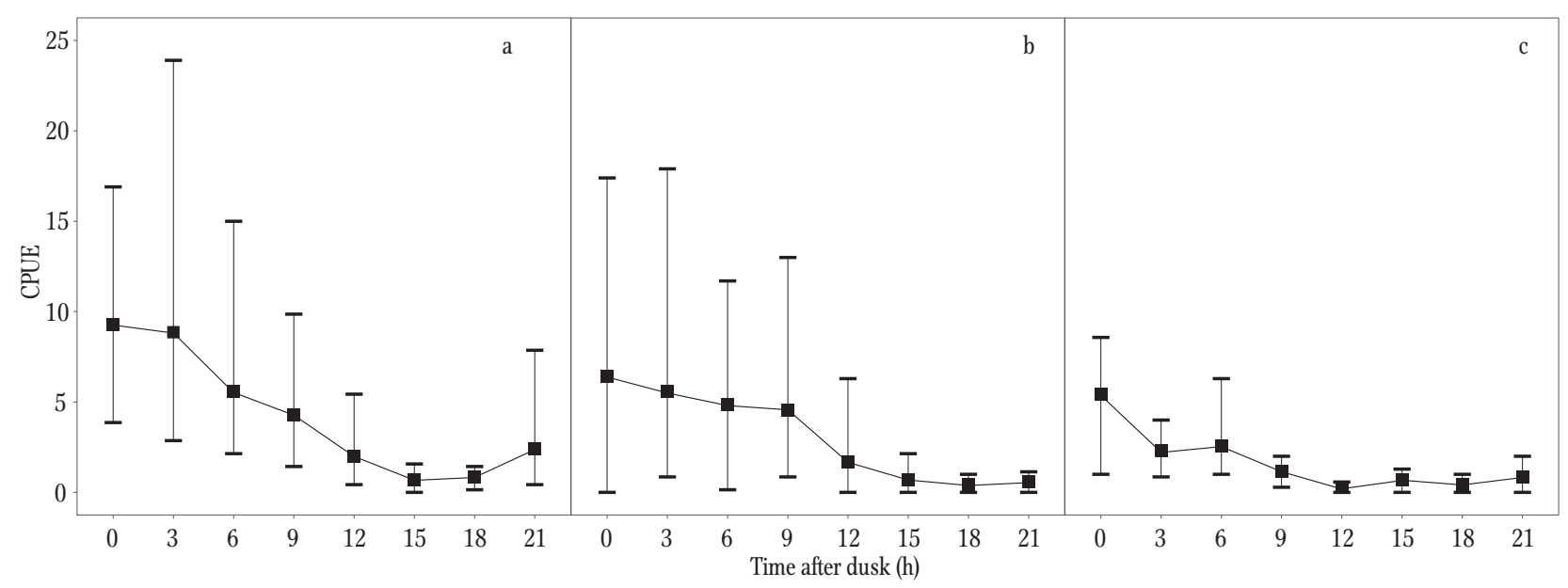

Figure 1. Mean ( \pm 95\% C.I.) abundance of (a) R. belingi, (b) R. kesslerii, and (c) S. baltica at different time intervals after dusk.

three most abundant species were: $R$. belingi $(237$ specimens at $5.0 \%$ of the total), R. kesslerii (174 specimens, 3.6\%), and S. baltica (96 specimens, $2.0 \%)$. The lengths of the individuals collected ranged between 12-93 $\mathrm{mm}$ SL for $R$. belingi (mean $46.2 \pm$ S.D. $16.5 \mathrm{~mm}), 25-76 \mathrm{~mm}$ SL for R. kesslerii (36.9 $\pm 7.6 \mathrm{~mm})$, and $21-75 \mathrm{~mm}$ SL for $S$. baltica $(58.1 \pm 7.7 \mathrm{~mm})$. Standard length did not differ among diel periods in any of these three species (GLMM, P > 0.05).

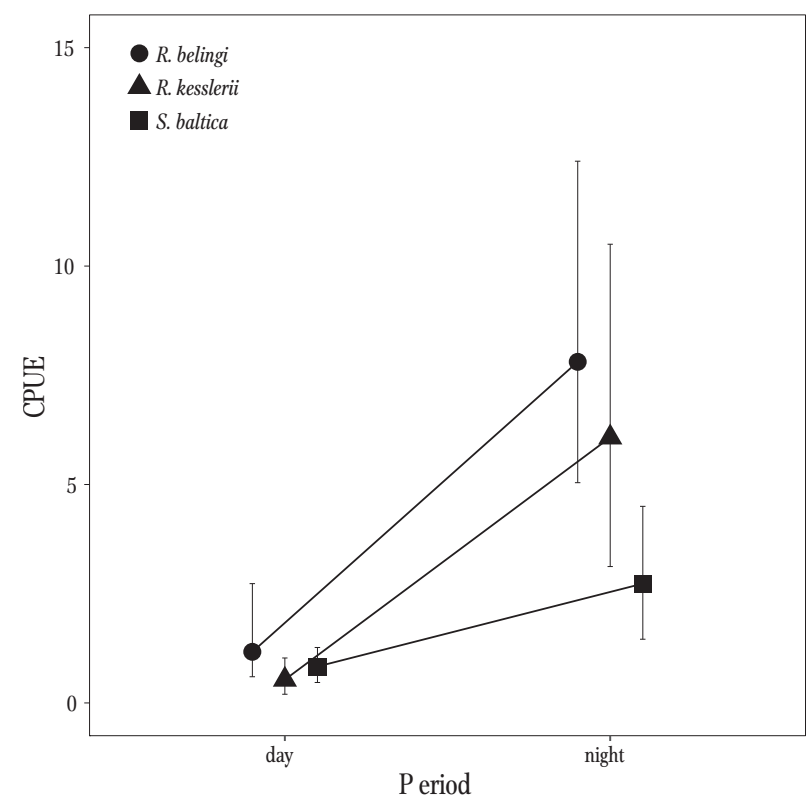

Figure 2. Mean ( $\pm 95 \%$ C.I.) day and night abundance of $R$. belingi, R. kesslerii, and S. baltica.
A clear diel pattern of abundance was found in all three species investigated (Fig. 1); they were caught in the highest numbers within the first $3 \mathrm{~h}$ after dusk. Then their abundance gradually decreased by approximately 0.88 to 0.89 times for every additional $\mathrm{h}$ after dusk (GLMM, $\mathrm{z}=-9.88, \mathrm{P}<0.001$ for R. belingi, $\mathrm{z}=-8.97, \mathrm{P}<0.001$ for $R$. kesslerii and $\mathrm{z}=$ $-7.00, \mathrm{P}<0.001$ for $S$. baltica). When all the observations were pooled into only two categories, nighttime abundance was 6.62 times higher than that of daytime for $R$. belingi (GLMM, $\mathrm{z}=10.32, \mathrm{P}<0.001$ ), 8.84 times higher for $R$. kesslerii $(\mathrm{z}=8.35, \mathrm{P}<$ $0.001)$, and 4.30 times higher for $S$. baltica $(\mathrm{z}=6.30$, $\mathrm{P}<0.001$ ) (Fig. 2).

\section{Discussion}

Romanogobio belingi, R. kesslerii, and S. baltica are small-bodied, bottom-dwelling fish species, which makes them particularly difficult to sample in large rivers with deep waters and low transparency, especially with electrofishing. These three species constituted up to $10.6 \%$ of all the fish collected during the study period. For comparison, only 14 specimens of $R$. belingi, 4 specimens of $R$. kesslerii, and no $S$. baltica were caught at 13 sites (each $1,000 \mathrm{~m}$ in length) on the Vistula River between the mouths of the Raba and Wisłoka rivers. Each of these sites was 
Table 1

Comparison of beach seining (this study) and electrofishing at corresponding river stretches (spring and fall sampling; Nowak, unpublished data); the species discussed in this study are highlighted in bold

\begin{tabular}{|c|c|c|}
\hline Species & $\begin{array}{l}\text { Beach } \\
\text { seining }\end{array}$ & Electrofishing \\
\hline Leuciscus leuciscus & 515 & 3 \\
\hline Alburnus alburnus & 425 & 439 \\
\hline Romanogobio belingi & 238 & 0 \\
\hline Romanogobio kesslerii & 174 & $\mathbf{0}$ \\
\hline Sabanejewia baltica & 96 & 0 \\
\hline Gobio gobio & 89 & 5 \\
\hline Squalius cephalus & 51 & 111 \\
\hline Chondrostoma nasus & 48 & 15 \\
\hline Vimba vimba & 45 & 0 \\
\hline Sander lucioperca & 37 & 0 \\
\hline Barbus barbus & 30 & 11 \\
\hline Blicca bjoerkna & 16 & 11 \\
\hline Leuciscus aspius & 7 & 3 \\
\hline Rutilus rutilus & 6 & 4 \\
\hline Pseudorasbora parva & 3 & 0 \\
\hline Alburnoides bipunctatus & 2 & 4 \\
\hline Carassius gibelio & 2 & 0 \\
\hline Gymnocephalus cernua & 2 & 0 \\
\hline Leuciscus idus & 2 & 3 \\
\hline Lota lota & 2 & 1 \\
\hline Perca fluviatilis & 2 & 8 \\
\hline Barbatula barbatula & 1 & 4 \\
\hline Cottus microstomus & 1 & 0 \\
\hline Scardinius erythrophthalmus & 1 & 1 \\
\hline Rhodeus amarus & 0 & 36 \\
\hline Abramis brama & 0 & 9 \\
\hline Silurus glanis & 0 & 7 \\
\hline Cyprinus carpio & 0 & 1 \\
\hline Esox lucius & 0 & 1 \\
\hline Species richness & 24 & 20 \\
\hline Total abundance & $1,812^{*}$ & 677 \\
\hline
\end{tabular}

* Including 14 specimens of unidentified cyprinid larvae

electrofished twice, in spring and in fall 2015 (Nowak, unpublished data). Moreover, electrofishing completely failed to record any of these species at the site where beach seining was performed (Table 1). This suggests that all three species might be seriously overlooked and their populations underestimated during routinely performed electrofishing.

Both of the gudgeon species, $R$. belingi and $R$. kesslerii, and S. baltica are considered species of primarily nocturnal activity (Ahnelt and Tiefenbach 1998, Bless and Riehl 2004, Przybylski 2012). Quantitative data on S. baltica are scarce, but there is a bulk of evidence that in temperate lowland rivers gudgeon species usually come inshore after dusk (Mathews 1971, Copp and Jurajda 1993, 1999, Koščo et al. 2008, Nowak 2017). Our results clearly show that nighttime samples might be several times (in the present study from 4.3- to 8.8-times, depending on the species) higher than those collected during the daytime. Similar conclusions have already been reached for different species in various habitats (Sanders 1992, Johnson and Covich 2000, Kocovsky et al. 2010, Szalóky et al. 2014, Zajicek and Wolter 2018), but these refer especially to small, bottom-dwelling fishes in large lowland rivers (Wolter and Freyhof 2004, Koščo et al. 2008, Lenhardt et al. 2017, Nowak 2017). However, in smaller water courses daytime samples might be fully representative of actual fish assemblages (Copp 2010 and literature therein, Czeglédi et al. 2016). Taking into account the restricted resources available for any monitoring program, it seems crucial to apply methods and gears that provide the best catch-to-effort ratios. Whereas nighttime electrofishing might not be preferable because of safety considerations, and only daytime electrofishing is approved by the national monitoring methodology (Makomaska-Juchiewicz and Baran 2012), using a relatively small seine net in shallow, unstructured habitats during periods of darkness seems both straightforward and efficient. Beach seining is one of the standard methods for monitoring fishes in North American rivers (Guy et al. 2009) and additional gears are commonly applied worldwide (e.g., Guy et al. 2009, Zajicek and Wolter 2018).

Differences in the day and night abundances of the species studied in this paper might be attributed 
to the varied catch efficiency of seine nets at different light levels (Pierce et al. 2001, Ř́ha et al. 2008). On the other hand, clear patterns of diel dynamics were found in all three species. If differences in abundance were to be attributed to different catch efficiency, such a gradual change in the numbers of the fish collected would be rather unexpected. Irrespective, when considering monitoring design it seems less important if the higher abundance of target species at dusk might be attributed to the specific aspects of their biology or to improved gear performance as far as it permits optimizing catch and effort.

The need for adapting monitoring techniques to specific attributes of target species or their habitats is often neglected, which can lead to biased results (Nunn et al. 2014, Lintermans 2015, Stewart et al. 2017). On the other hand, sound data on distribution and abundance are crucial for every management plan of endangered or rare species. The present study demonstrates that for $R$. belingi, $R$. kesslerii, and $S$. baltica beach seining after dusk might be very efficient. For this reason we strongly recommend considering it as a supplementary inventory technique in monitoring programs targeting any of these three species. Obviously, the standardization of this method for the requirements of monitoring is beyond the scope of this paper and should be done based on a much broader spatial scale.

Acknowledgements. This study was supported by NCN project No. 2013/09/N/NZ9/01448 (to M.N.). We are obliged to two anonymous reviewers for their valuable comments on an earlier version of this manuscript.

Author contributions. M.N. designed the research; M.N., A.K. and P.S. performed the field sampling; M.N. and W.P. analyzed the data; M.N. wrote the manuscript.

\section{References}

Ahnelt H., Tiefenbach O. 1994 - Verbreitungsmuster zweier Steinbeißerarten (Cobitis aurata, Cobitis taenia) im Einzugsgebiet der Mur (Österreich) - Fischökologie 7: 11-24.
Bates D., Maechler M., Bolker B., Walker S. 2015 - Fitting linear mixed-effects models using lme4 - J. Stat. Soft. 67: $1-48$.

Bless R., Riehl R. 2007 - Diurnal activity, mating behavior and structure of the egg envelopes in four species of Danubian gudgeons (Cyprinidae) - Bull. Fish Biol. 9: $1-12$.

Casselman J.M., Penczak T., Carl L., Mann R.H.K., Holčík J., Witowich W.A. 1990 - An evaluation of fish sampling methodologies for large river system - Pol. Arch. Hydrobiol. 37: 521-551.

Copp G. H. 2010 - Patterns of diel activity and species richness in young and small fishes of European streams: a review of 20 years of point abundance sampling by electrofishing - Fish Fish. 11: 439-460.

Copp G. H., Jurajda P. 1993 - Do small riverine fish move inshore at night? - J. Fish Biol. 43 (Suppl. A): 229-241.

Copp G. H., Jurajda P. 1999 - Size-structured diel use of river banks by fish - Aquat. Sci. 61: 75-91.

Czeglédi I., Sály P., Takács P., Dolezsai A., Vitál Z., Nagy A. S., Erôs T. 2016 - Do diel variations in stream fish assemblages depend on spatial positioning of the sampling sites and seasons? - Acta Zool. Acad. Sci. Hung. 62: 175-190.

De Leeuw J.J., Buijse A.D., Haidvogl G., Łapinska M., Noble R., Repecka R., Virbickas T., Wiśniewolski W., Wolter C. 2007 - Challenges in developing fish-based ecological assessment methods for large floodplain rivers - Fisheries Manag. Ecol. 14: 483-494.

Freedman J.A., Stecko T.D., Lorson B.D., Stauffer J.R.Jr. 2009 - Development and efficacy of an electric benthic trawl for sampling large-river fish assemblages - N. Am. J. Fish. Manage. 29: 1001-1005.

Guy C.S., Braaten P.J., Herzog D.P., Pitlo J., Rogers R.S. 2009 - Warmwater fish in rivers - In: Standard methods for sampling North American freshwater fishes (Eds) S.A. Bonar, W.A. Hubert, D.W. Willis, American Fisheries Society, Bethesda, Maryland: 89-84.

Haddon M. 2011 - Modelling and quantitative methods in fisheries. 2nd Ed - Chapman and Hall, London: 1-471.

Herzog D.P., Ostendorf D.E., Hrabik R.A., Barko V.A. 2009 The mini-Missouri trawl: A useful methodology for sampling small-bodied fishes in small and large river systems - J. Freshwat. Ecol. 24: 103-108.

Janáč M., Jurajda P. 2013 - Diel differences in 0+ fish samples: effect of river size and habitat - River Res. Appl. 29: 90-98.

Johnson S.L., Covich A.P. 2000 - The importance of night-time observations for determining habitat preferences of stream biota - Regul. Rivers Res. Manage. 16: 91-99.

Kocovsky P.M., Stapanian M.A., Knight C.T. 2010 - Night sampling improves indices used for management of yellow perch in Lake Erie - Fisheries Manag. Ecol. 17: 10-18. 
Koščo J., Pekárik L., Nowak M., Košuthová L. 2008 - Diel changes in fish assemblages in rivers of Eastern Slovakia - In: Proc. XI Czech Ichthyol. Conf. (Ed.) R. Kopp, MZLU, Brno: 126-131 (in Slovak).

Kotusz J. 2017 - Golden loach Sabanejewia aurata. Results of monitoring in 2015-2016 - GIOŚ, Warszawa, http://siedliska.gios.gov.pl/images/pliki_pdf/wyniki/20 15-2018/2016/zwierzeta/wyniki_monitoringu_zwierzat _2015_2016_koza_zlotawa.pdf (in Polish).

Lenhardt M.B., Pekarik L., Skorić S.B., Smederevac-Lalić M.M., Hegediš A.E., Jaćimović M. L., Djikanović V.D. 2017 - Influence of the twilight period and different sampling methods on catch of gobiids (Gobiidae) at four locations in the inshore parts of the Danube River - Acta Zool. Bulg. Suppl. 9: 225-229.

Lintermans M. 2015 - Finding the needle in the haystack: Comparing sampling methods for detecting an endangered freshwater fish - Mar. Freshwat. Res. 67: 1740-1749.

Mangiafico S. 2018 - rcompanion: functions to support extension educaton program evaluation - $\mathrm{R}$ package, https://CRAN.R-project.org/package=rcompanion.

Mathews C.P. 1971 - Contribution of young fish to total production of fish in the River Thames near Reading - J. Fish Biol. 3: 157-180.

Nowak M. 2017 - Diel and seasonal variation of fish assemblages in selected stretches of the Nida River - PhD theses, University of Agriculture in Kraków, 106 p. (in Polish).

Nowak M., Klaczak A., Szczerbik P., Mendel J., Popek W. 2013 - Rapid range expansion of the "whitefin" gudgeon Romanogobio cf. belingi (Teleostei: Cyprinidae) in a lowland tributary of the Vistula River (Southeastern Poland). Ann. Limnol. - Int. J. Lim. 49: 319-326.

Nowak M., Klaczak A., Szczerbik P., Mendel J., Popek W. 2014 - Occurrence of the Kessler's gudgeon Romanogobio kesslerii (Dybowski, 1862) (Cyprinidae) in the Upper Vistula River (Poland) - J. Appl. Ichthyol. 30: 1062-1064.

Nunn A.D., Tewson L.H., Bolland J.D., Harvey J.P., Cowx I.G. 2014 - Temporal and spatial variations in the abundance and population structure of the spined loach (Cobitis taenia), a scarce fish species: Implications for condition assessment and conservation - Aquat. Conserv. 24: 818-830.

Pierce C.L., Corcoran A.M., Gronbach A.N., Hsia S., Mullarkey B.J., Schwartzhoff A.J. 2001 - Influence of diel period on electrofishing and beach seining of littoral fish assemblages - N. Am. J. Fish. Manage. 21: 918-926.

Przybylski M. 2012 - Golden loach Sabanejewia aurata - In: Monitoring of animal species. Methodological handbook. Part III (Eds) M. Makomaska-Juchiewicz, P. Baran, GIOŚ, Warszawa: 223-235 (in Polish).

R Core Team 2018 - R: A language and environment for statistical computing - R Foundation for Statistical Computing, Vienna, Austria, https://www.R-project.org/.

Ř́ha M., Kubečka J., Mrkvička T., Prchalová M., Čech M., Draštík V., Frouzová J., Hladík M., Hohausová E., Jarolím O., Jůza T., Kratochvíl M., Peterka J., Tušer M., Vašek M. 2008 - Dependence of beach seine net efficiency on net length and diel period - Aquat. Liv. Res. 21: 411-418.

Sanders R.E. 1992 - Day versus night electrofishing catches from near-shore waters of the Ohio and Muskingum Rivers - Ohio J. Sci. 92: 51-59.

Stewart D.R., Butler M.J., Harris G., Johnson L.A., Radke W.R. 2017 - Estimatin abundance of endangered fish by eliminating bias from non-constant detectability Endanger. Species Res. 32: 187-201.

Szalóky Z., György Á. I., Tóth B., Sevcsik A., Specziár A., Csányi B., Szekeres J., Erős T. 2014 - Application of an electrified benthic frame trawl for sampling fish in a very large European river (the Danube River) - Is offshore monitoring necessary? - Fish. Res. 151: 12-19.

Witkowski A., Kotusz J., Przybylski M. 2009 - The degree of threat to the freshwater ichthyofauna of Poland: Red list of fishes and lampreys - situation in 2009 - Chrońmy Przyr. Ojcz. 65: 33-52 (in Polish).

Wolter C., Freyhof J. 2004 - Diel distribution patterns of fishes in a temperate lowland river - J. Fish Biol. 64: 632-642.

Zajicek P., Wolter C. 2018 - The gain of additional sampling methods for the fish-based assessment of large rivers Fish. Res. 197: 15-24. 